\begin{tabular}{l} 
RCCS \\
\hline Annual Review
\end{tabular}

\section{RCCS Annual Review}

A selection from the Portuguese journal Revista Crítica de Ciências Sociais

$3 \mid 2011$

Issue no. 3

\title{
The Content of the Form and other Textual Politics. Configurations of Nationhood and Citizenship in Disgrace and Agaat
}

\section{Rosemarie Buikema}

\section{(2) OpenEdition}

\section{Journals}

\section{Electronic version}

URL: http://journals.openedition.org/rccsar/295

DOI: $10.4000 /$ rccsar.295

ISSN: $1647-3175$

\section{Publisher}

Centro de Estudos Sociais da Universidade de Coimbra

\section{Electronic reference}

Rosemarie Buikema, "The Content of the Form and other Textual Politics. Configurations of

Nationhood and Citizenship in Disgrace and Agaat », RCCS Annual Review [Online], 3 | 2011, Online since 01 October 2011, connection on 01 May 2019. URL : http://journals.openedition.org/rccsar/295 ; DOI : 10.4000/rccsar.295 


\section{Rosemarie Buikema}

Utrecht University, the Netherlands

\section{The Content of the Form and other Textual Politics. Configurations of Nationhood and Citizenship in Disgrace and Agaat ${ }^{*}$}

This text seeks to rethink the relationship between literature and citizenship or, more generally, identity. It does so by analysing two recent South-African novels i.e. J.M Coetzee's Disgrace (1999) and Marlene van Niekerk's Agaat (2006). Both Disgrace and Agaat are examples of how the singularity of great literary works needs an interdisciplinary approach that does justice to the way in which a novel is part of, and simultaneously co-constructs, the discourses on history, identity and citizenship.

Keywords: literature; identity; difference; citizenship; representation; literariness; J.M Coetzee; Marlene van Niekerk.

In outlining the relationship between literature, community building and citizenship, two South African novels will guide my course: Disgrace (1999) by J.M. Coetzee and Agaat $(2004)^{1}$ by Marlene van Niekerk. The work of both has become the focus of fierce debate with respect to the exact relation between literature, citizenship and nation building, or, more generally speaking, the relation between literature and identity. The nature of such discussions is exemplary for the practice of interpretation within cultural studies in the $21^{\text {st }}$ century. These two novels then, and the debate they have engendered, will act as a touchstone for proposing certain coalitions between the different forms of studying culture within the humanities.

Disgrace appeared in 1999, exactly a year after the publication of the massive five-volume Truth and Reconciliation Commission of South Africa Report (TCR). The novels' narrative events are centred on the white South African literary scholar David Lurie who makes the mistake of starting an affair with a coloured female student. He is subsequently dismissed. When he seeks peace and quiet on the farm of his daughter Lucy, both of them fall victim to violence by blacks.

Nearly every critic noticed that the story of the downfall of Professor David Lurie could be read as a description of the upheaval of a country in transition. The representation of this upheaval drew considerable national and international attention and sparked a continuous

\footnotetext{
* Article published in RCCS 89 (June 2010).

${ }^{1}$ This novel was originally published in Afrikaans. The first English translation was published in South Africa by Jonathan Cape Publishers in 2006.
} 
debate about what readers felt was Coetzee's pitch-black vision on the near future of South Africa. The fact that there were clear-cut differences between black, white and genderspecific interpretations of the novel was a striking feature of this heated debate. Black readers and critics characterized the trenchant images of black violence as unproductive and stereotypical, while white readers saw the way in which the white Lucy takes her historical colonial guilt upon her shoulders as far too fatalistic (Banville, 2000; Gorra, 1999). Feminist readings, moreover, criticised the affirmation of the connection between passivity and femininity (see also Krog, 2004). For instance, the literary scholar Elleke Boehmer wondered whether reconciliation in the context of a violent history is possible if women, in this case the white Lucy or the wife of the black Petrus, are still expected to bear gender-specific inequality and suffer in silence (Boehmer, 2002).

The novel Agaat was published five years later, in 2004. Its author is that other giant of South African literature, Marlene van Niekerk. In Agaat the reader witnesses the complex interaction between the dying white farmer's wife Milla and her black carer Agaat. Milla is paralyzed and unable to talk. Throughout the novel she tries to communicate with Agaat by moving her eyes. The two women, who are condemned to each other as patient and carer in the narrative present, share a heartrending and complex past which is unravelled bit by bit when Agaat reads fragments of Milla's dairy to Milla on her deathbed.

This novel too fell prey to a debate about the kind of things Van Niekerk tries to say about the future of South Africa. Van Niekerk is an Afrikaans speaking author who also writes in that language, and the South African reception of her novel concentrates specifically on the position allocated to the endangered Afrikaner minority culture in her vision of post apartheid South Africa. There were serious allegations from the politically conservative wing in particular, who blamed Van Niekerk for squandering Afrikaner heritage. The cultural philosopher Johann Rossouw accused Van Niekerk of pleading for the 'selfopheffing' (voluntary elimination) of Afrikaner culture in favour of an opportunistic association with a globalising English-speaking South African cultural elite (Rossouw, 2005). This led to a response by Andries Visagie, lecturer in Afrikaans and Dutch, who challenged Rossouw in an essay titled "Agaat as cultural archive for the future" in the digital South African journal Litnet (Visagie, 2007). Visagie agrees with the view that Agaat is a comment on the position of Afrikaner culture, but he is somewhat more sensitive to the novel's complexity. He is at a loss to understand how Rossouw can argue that Van Niekerk treats Afrikaner culture as a 
lost cause in Agaat. The novel informs the reader at length about the richness of Afrikaner folksongs, proverbs, children's rhymes, crafts, agricultural methods, sound farmer's lore and other traditions still available to the Afrikaans-speaking South African. This is no "selfopheffing," but the acknowledgment of a sub-cultural canon. What Agaat does undermine, according to Visagie, is the self-evident legitimacy and status of this cultural heritage in Afrikaner ideology. This status needs to be reformulated and that is why the novel may function as an archive of the future.

In the Netherlands too the journalistic reception of Agaat explicitly states that the lengthy novel's true meaning is allegorical. In an admiring review in de Volkskrant (12 May 2006), Fred de Vries writes for instance that "Agaat is an allegory of Afrikaner history of the past fifty years." He carefully connects the dates of the family story to historical facts. The birth of Agaat coincides with the institutionalization of apartheid in 1948, and the birth date of another central character recalls the Sharpeville protest instigated by schoolchildren in 1960 . De Vries sees the subtle symbiotic power play between the white Milla and the black Agaat as metaphorical for racial and political relations in South Africa. Milla's progressive muscular disease is symbolical of the exhaustion of farmland and the decline of Afrikaner hegemony. And so on.

\section{Art and Community Building}

The cultural and literary critics mentioned above are aware of the fact that in these specific novels, art on the one hand, and political and historical reality on the other, have entered into a cogent relationship. It is of course true that works of art that are rooted in a period of political transition have a self-evident urgency and significance that cannot easily be claimed by all art. However, in less pressing political circumstances cultural artefacts also present opportunities for identification and are in that sense community building, which involves excluding and including groups. In the past decades, the identity constituting effects of art and its concomitant inclusionary and exclusionary mechanisms have featured in various disciplines within the humanities. More generally, art and culture are seen as important producers of cultural memory in any context (see for instance Bal et al., 1999). The underlying idea is that cultural artefacts come about in a force field of global and local developments and that, as a sign system and text, the work of art has an openness and mobility that Bakhtin and Kristeva have described with the term "intertextuality" (Bakhtin, 
1982; Kristeva, 1974). Their concept of intertextuality is not exclusively limited to literary examples. Every sign system absorbs other intended and unintended sign systems. Bakhtin's famous dictum that "the word does not forget its own path" always illustrates this process best. That is to say that every text bears the echoes of other texts and is also in dialogue with other texts, which implies that the attribution of meaning is a project that is never fully realised. A reader then performs a text, rather like a musician who performs a score (see also Van Heusden, 2001). The performance determines the attribution of meaning, distributes emphasis, and reinforces some strands while ignoring others.

Thus, in order to do justice to the intertextual character of the artefact, texts can only be studied adequately, when they are the object of research, from an interdisciplinary perspective. Interdisciplinarity is in essence not a frivolous type of academic research, as critics of cultural studies have frequently claimed, but a necessity compelled by the research object itself if a cultural phenomenon is to be approached in all its complexity. Aesthetic experience is no longer exclusively related to work-immanent aspects, but linked to material, political and historical circumstances as well.

The outcome of research carried out from this angle has yielded some very valuable results and changed many a classic literary work's meaning forever. After Toni Morrison's lectures in American literature at Harvard University (see Morrison's Playing in the Dark, 1992), who could fail to grasp that the construction of freedom and humanity in Mark Twain's great American novel Huckleberry Finn (and the many films of the book) is inextricably connected to the slavery of nigger Jim? Who is still willing to present Jane Eyre as an unproblematic feminist heroine since Gayatri Spivak (1985) showed us that Jane's striving for economic independence, so applauded by the second feminist wave, was enabled by the unrestrained imperialism and slavery of nineteenth-century Britain? In the past decades, the teaching and research in feminist cultural criticism has been solidly anchored in this tradition of critical interpretations of culture. The intertextual approach has proven to be just as fruitful to research of popular culture as to art research. However, a specific practice has crept into the enthusiasm of committed humanities scholars: the concept of intertextuality is mainly applied as a form of ideological criticism. Many a committed research project in the humanities is in danger of reducing popular culture and artistic expressions to a message about the construction of gender, ethnicity, nationality and/or sexuality, thereby paying too little attention to the specific nature of the medium and 
the effect of its form. The approach to the artistic domain with a clear-cut political agenda involves the risk of losing sight in advance of what constitutes the specificity of art and literature. A few years ago, Jonathan Culler, a worthy advocate of intertextual interpretations of art and culture, concluded that, as a literary scholar, he had been so busy conceptualising gender, race, identity, and subjectivity that not a word is spent on literariness in his prominent introductions to literary theory (Culler, 2000; see also Butler, 2000; Spivak, 2003).

To a certain extent this practice mirrors the white, black and gendered readings of Coetzee quoted at the beginning of my essay and the concern about the loss of Afrikaner cultural heritage in response to Van Niekerk's latest novel. I mean to attempt to redress this imbalance in proposing a synthesis of the work-immanent approach, so deservedly criticised in the past, and the contextual approach to art and culture that was so rightly taken on board. In other words, I would like to reassess the fruitfulness of the work-immanent approach and the method of meticulous textual analysis involved in it in order to attune and enrich the intertextual approach and avoid the risks inherent to identity politics in the interpretation of art. Form is what defines a work of art; form constitutes its singularity par excellence, which is why it will always withdraw from being appropriated by sheer identity politics. I have no wish to deny that issues of identity politics can be understood through and illustrated by a work of art. However, the fictive and imaginary character of art does imply that the way in which it represents political and historical themes deserves explicit methodological attention.

\section{Literature as the representation of difference}

Let us return to the two contentious South African novels. Apart from the vehement debate about how to be a white citizen in post-apartheid South Africa that was caused by these two novels, the most conspicuous similarity in the reception of Disgrace and Agaat is that both novels invariably seize readers by the throat. As such, this is of course a significant literary phenomenon; and this ought to be the primary focus of literary and cultural criticism. We are living in a multimedia world increasingly dominated by visual culture, digital or not. How is it possible, then, that in this kind of world a written text can seize you, perturb you, become part of your consciousness? Critics like Susan Sontag and Walter Benjamin would have said perhaps that this is possible because literature is a work of art. Every work of art 
has a unique aura that leads to concentration and contemplation (Benjamin, 1935; Sontag 1964). Roland Barthes calls a similar effect in photography the punctum, whose immediacy stirs the art critic although it withdraws from connotative signification (Barthes, 1980). Asking this kind of questions changes the focus from meaning to the signifier, to the materiality of the work. In the case of literature, such materiality is the specific literariness of the work.

But what is literariness? It is a question frequently asked and variedly studied in literary studies, to no fully satisfactory effect. In an attempt to describe literariness here, I would say that literariness is generally manifested where an awareness or consciousness of 'the real' is engendered by language. This term, the real, originates from linguistics as inspired by French psychoanalysis. Like the concepts of aura and punctum, it refers to that which produces an effect, but which is not embedded in the symbolic system. In other words, in this context 'the real' refers both to the deficit of language and to the surplus, i.e. excess, of the medium. From this perspective, literariness is language that reflects on its own performance. I have to admit that this sounds rather vague at first, but in the past decades semioticians of culture have managed to find a connection between awareness of the real and the process of attributing of meaning (Culler, 1981, 1983). Awareness of the real develops through difference and divergence. People experience the real at the moment the world appears to them in unexpected ways. I argue that the literary or artistic moment is the imitation of that process. Hence, it is the mimesis of the unexpected instead of the imitation of a familiar reality which creates awareness. Paradoxically, then, diverging linguistic forms make us aware of our conventionally coded ways of dealing with the world.

The nature and effect of literature is different from other social and cultural practices because of this specific form of semiosis. Mimesis of the divergent also accounts for the fact that literature in particular, although this is true for art in general as well, can focus on absolutely everything. But whatever it deals with, its most important effect is always the production of awareness. Being aware of difference. Literature performs and represents an awareness of alterity, of the other, of what is new and different. Thus, literariness comprehends the dimension of language that has the capacity to reveal the world. It has the potential to create new realities, not by giving us what we want, but by dissecting and deconstructing our expectations. Literature does not present us with solutions for questions 
concerned with identity politics or other matters, but foregrounds those questions as such by telling stories and by situating characters in diverse locations and times.

\section{Disgrace}

How does this process take place in Disgrace and Agaat? Which questions do Coetzee and Van Niekerk raise in depicting certain characters, locations and times? How does the analysis of culture that I am advocating raise these texts above reductive readings that are exclusively based on identity politics and/or on allegory? Let us start with Coetzee: in Disgrace, Coetzee seems especially to be asking questions about the specific characteristics of language. Which different kinds of languages are available to us? What can and cannot be achieved by language with respect to the relation of the subject to itself and the regulation of human interaction?

The investigation into the possibilities and limitations of language motivates every plot development in David Lurie's story. The most prominent example of this is Lurie's somewhat unthinking seduction of a female student in his class. He is summoned before a committee of enquiry consisting of his closest colleagues. If he is willing to tell the committee in just a simple phrase that he sees the error of his ways, that he has transgressed academic conventions, the problem will blow over and order will be restored. You tell us your story and we will offer our forgiveness. That is the function of language as exchange, as trade-off. Because of Lurie's awareness of the reductive effects of that communicative function of language, however, the self-evident nature of it in this specific context becomes unstuck.

An exchange or trade-off presupposes an abstract equality. There is no room for difference in an exchange. Language as a means of communication and thus as exchange, Lurie seems to be saying, allows me to confess guilt and to accept the consequences of my deeds, but it does not serve to reveal my deepest motives in unequivocal terms or to express remorse. He thus accepts his dismissal.

It is of course tempting to read this reflection on the scope of language in relation to perpetrators and victims as a comment on the truth and reconciliation process that had come to an end just before the publication of Disgrace. There is in fact no reason for not reading it in this way. Reports on the truth and reconciliation process not only focused on the stories of the victims of the apartheid regime but also, and especially, on the stories of the perpetrators. Perpetrators could divulge their story to a committee specifically set up for 
this purpose and would duly receive amnesty (see for example Coetzee and Nutall, 1998). This aspect became a target of much criticism because of the relative ease with which the perpetrators could clear their conscience by simply telling a pretty story (Mamdami, 2001; Minow, 1998; James and Van de Vijver, 2001). Lurie's refusal to confess in order to be pardoned can be read as a critique on that political-historical reality.

However, there is a good reason to go beyond this broad contextual reading and to regard Coetzee's novel in the context of his other works. The occupation with the performative aspect of language has been a recurrent theme in his novels and essays since his debut Dusklands in 1974, thus preceding the work of the Truth committee in South Africa by twenty years (see also Attridge, 2005). Coetzee's impressive essay "Confession and Double Thoughts" (1985; in Coetzee, 1992) testifies to his interest in this theme. In attempting to formulate a critique on any effort to hound the truth by means of a written or spoken confession and/or self-examination, he concludes that every confession involves "double thoughts," ulterior motives. He argues that the confessional process can never imply an unequivocal pursuit of truth and self-awareness because every revelation of a hidden truth also simultaneously serves another aim. In other words, the confessional mode leads to a paradoxical situation: the truth is veiled rather than unveiled. Only when confession is not aimed at self-preservation or meant to command sympathy and acceptance on the part of the listener/reader, there is a possibility that truth be revealed-as a matter of grace.

In the context of the pursuit of truth and the truthfulness of expressed regret, the use of language as unequivocal exchange - you will tell your story and I will seal your fate advances the question of how justice can be done, and what justice should look like. That question resurfaces even more compellingly in the second half of Coetzee's novel. Having left Cape Town, Lurie moves in with his daughter Lucy who, with the help of coloured employees, manages a farm in the Eastern Cape. The apotheosis of this second part is the violence inflicted on father and daughter by acquaintances of Lucy's black employee Petrus. Lurie wishes to solve the injustice against his daughter in the same way he solved his own faux pas - by taking recourse to the law. Not by enforcing remorse or understanding the reason why, but through the economy of the law. Whoever breaks the law will be punished. With dismissal, a fine, or detention. Again, such an exchange of guilt and penance makes it impossible to acknowledge that the histories and motives of everyone concerned are fundamentally different and cannot be weighed equally. Despite her father's persistent 
urgings to report the crime and go to court, the white Lucy accepts what has been done to her just as the TRC asks of the black population to give and forgive. No equivalent exchange, no justice, but a gift.

It is precisely for this dramatic turn in the plot that Coetzee is severely criticised by white and feminist readers. When Lucy informs her father that she entirely accepts the consequences of the situation and renounces any claim of retribution, Lurie concludes that she is acting like a dog. This is true, she agrees, like a dog. Being dog-like, however, does not imply passive resignation as Elleke Boehmer fears, nor a programmatic solution to a problem, an end point, as some white critics inferred from the text. It is an opportunity to remain open to the experience of the present and continue to be oriented on the future. Such an interpretation becomes probable if we apply the work-immanent approach and are made sensitive to the way in which the vocabulary of confession and awareness does not concern the thematic of the novel alone, but affects the language of the novel as well. Once Lurie realises that his emphasis on the logic of justice will only distance him further from his daughter and her employers, he is able, through his dedication to written-off dogs and in his thinking about music, to approach a level of humanity he was lacking before. In the novel's closing pages, Lurie mostly finds himself among the dogs in their shelter, while thinking about music:

He sighs. It would have been nice to be returned triumphant to society as the author of an eccentric little chamber opera. But that will not be. His hopes must be more temperate: that somewhere from amidst the welter of sound there will dart up, like a bird, a single authentic note of immortal longing. As for recognizing it, he will leave that to the scholars of the future, if there are still scholars by then. For he will not hear the note himself, when it comes, if it comes - he knows too much about art and the ways of art to expect that. (Coetzee, 1999: 214)

Using staccato sentences Lurie enters the twilight zone between language and nonlanguage, between human and animal, black and white, man and woman. The awareness that one can only become human in being dedicated to the other, to music, to difference, is a political effect of Disgrace's literariness, of Coetzee's sparse language, of the room for thought the reader is offered. Read within the context of post-apartheid South Africa, this complex stance does not necessarily obstruct the path towards reconciliation; but it highlights the as yet unbridgeable gaps between different political-historical histories and opens an outlook on human interaction that is not facile but 'real.' That is what art can 
contribute to the debates on identity and citizenship. The divergent story creates an awareness of our conventionally coded ways of dealing with the world.

\section{Agaat}

Current political debates on culture, identity and citizenship tend to turn to concepts like hybridity, nomadism, cosmopolitism, diversity and the like. Thus far I implicitly have argued for a very specific interpretation of those concepts which all try to describe the multilayeredness and situatedness of the subject. In my discussion of literature and the configuration of citizenship, hybridity, nomadism or diversity are not so much politically correct concepts that pay lip service to the experiences of women, migrants, blacks and other politically, socially and culturally marginalised people, as the consequence of the fundamental singularity of visual and discursive works of art (see also Attridge, 2004; Braidotti, 2006). This singularity does not reside in the inviolable meaning that is buried in the deep structure of the work, as a work-immanent approach would assume. Singularity resides in the complex of intertextual and contextual machinations. So in the case of the literary work the singular effect comes about through the interplay of language, genre and literary tradition, as well as the cultural and geopolitical context in which the work functions.

I began my essay with a brief sketch of the cultural and geopolitical context in which both Disgrace and Agaat have become part of a comparable cultural political debate. I have shown that, as a literary event, there is more to Disgrace than mere participation in a political debate. In conclusion, I would like to sketch briefly how Agaat differs from Disgrace as a literary event.

Apart from imagining a country in transition, Agaat also sheds a light on a wholly different world. Thematically just as grand and burdensome, and equally concerned with concepts of language, justice, and the law, with the representation of the unincorporable other and difference, the style and choice of words in Agaat is strikingly suggestive. While Coetzee is economic with language - his sentences are terse, jagged, disembodied, almost mathematical, leaving aside their sometimes lyrical textual effect - Marlene van Niekerk's novel Agaat is a sumptuous linguistic orgy, a blazing volcano of words, an excessive mix of styles and genres.

For that reason a description of the plot of this novel is in no way representative of its potential impact as a literary event. I will try nevertheless. More than forty years ago the 
white Milla inherited the settlement Grootmoedersdrift. She has ambitious plans for the land and the premises and learns to master traditional agricultural methods. In order to endure her loveless and childless marriage to Jak, Milla takes in the coloured Agaat as a foster child. She treats the neglected child like she treats the South African land: with traditional methods. She sways between regarding the child as a small animal that can be transformed into a human being through discipline and punishment and seeing it as an enigma that needs to be deciphered or as a potential source of love, gratitude and admiration that needs to be cherished. When about twelve years have past Milla becomes pregnant, contrary to all expectations. Agaat is demoted from adopted daughter to servant. Agaat's revenge on Milla is ingenious and has very complex effects. She deploys the stereotypical conduct of the wet nurse and the black mama and uses her love to steal Milla's son. The child Jakkie develops a symbiotic relationship with this self-appointed mother and from their son's earliest youth his biological parents Milla and Jak are of no account.

In the tradition of South African literature, the setting and themes of Agaat appear to typify the novel as a so-called plaasroman. This is an essentially conservative nationalistic nineteenth and twentieth-century colonial genre. Its prominent themes are the connection to the land, the spacious countryside, the motif of the lost son, the relation to earlier generations, and especially the distinction between a white 'us' and a black 'them' (Coetzee, 1988; Jansen, 2005; Postel, 2006). However, in Van Niekerk's novel the settlement is far from idyllic. Grootmoedersdrift is a hotbed of unfulfilled desire, failed investments and projects going nowhere, cold-heartedness, violence, revenge and tyranny. In that sense Van Niekerk innovates the traditional genre from a post-apartheid position, comparable to the way in which in the eighties Angela Carter (1983: 69) advocated playing a postmodernist feminist and post-colonial game with conventional themes and genres: "I am all for putting new wine in old bottles especially if the pressure of the new wine makes the old bottles explode." This would imply that Rossouw has a point: Van Niekerk undermines classical Afrikaner values and sentiments. But that is not the whole story. More than in any other plaasroman the tie with the land and the spaciousness of the countryside are apparent in Agaat both through its themes and composition as well as in the limitless exploration of the linguistic sign. Van Niekerk investigates the possibilities of language to an extreme extent and it is indeed true that here she challenges the boundaries of the traditional plaasroman and its patriarchal, nationalist values. Her method fits Hélène Cixous' use of the French verb 
voler in the familiar double meaning of the word (Cixous, 1975). Innovating literary tradition is like an act of voler, a process of theft and flight. In Van Niekerk's novel flight transforms the stolen form, the signifier, into an almost palpable object that allows for the celebration and re-appropriation of the colours and fragrances of the African land. Thus, reading for example about Milla's struggle against agricultural monoculture is not so much a mental as an almost physical experience. In the novel's structure Milla's dying body acts like a text, an interactive source carrying the burden of a past event; it has memory; it is coded and conditioned but not fixed in time. In the meantime the reader is inevitably caught in the tangle of love and revenge, innocence and guilt, justice and injustice, power and impotence.

It is also this brazen imaginativeness and nearly palpable embodiment of frustrated and corrupted desire that made Van Niekerk the target of the type of criticism voiced by Rossouw, who argues that the minute description of Milla's dying body, doomed to silence and at the mercy of the black Agaat, means that Van Niekerk is squandering South Africa's cultural heritage.

Certainly in the case of a work like Agaat, such criticism implies an almost hostile view on art, an anti-literary reading of literature and a disregard of the paradoxical dynamics of power relations between the characters. In order to give an example of one of the many deregulating literary registers deployed by Van Niekerk in the midst of the vortex of disaster and violence, I will quote a random passage in which Milla Redelinghuys is thinking of Agaat while on her deathbed. The passage is an example of the succession of subtly shaded and suggestively fragrant miniatures. As I said before, Milla is paralysed, she is unable to speak and she is at the mercy of Agaat:

'Ag, that I could speak now! I would want to ask her if she remembers. The butterflies we picked out of pools. After the showers that fell unseasonably that first year after I got her. Too heavy to fly, trapped by the rain. We took them out of the mud, blew on the stuck-together wingtips until we found fingerholds, carefully, carefully like wet scraps of tissue paper we pulled the wings apart so that one shouldn't come off on the other.' (2006: 538)

While the vocabulary of subjection to the law and its violation and of confession, guilt and awareness carries the weight of Disgrace, the power of Agaat lies in the unprecedented abundance of poetic language, in linguistic associations and stylistic experiments, in the deployment of novel words, images, and streams of consciousness. Every little miniature, like the one cited above, shows that this novel does not lend itself to a univocal identity- 
constituting appropriation. At the same time, the experimental style and the poetic language demonstrate that in a context of racial and patriarchal violence, literariness and politics do not constitute separate domains. Far from wishing to reduce Agaat to a programmatic cultural studies object, I would recommend this unique and exemplary novel as a guide in further exploring the interaction between content and form, literariness and politics, literature and citizenship in the years to come.

\section{References}

Attridge, Derek (2004), The Singularity of Literature. London and New York: Routledge.

Attridge, Derek (2005), J.M. Coetzee and the Ethics of Reading. Scottsville: University of Kwazulu Natal Press.

Attwell, David (1993), J. M. Coetzee: South Africa and the Politics of Writing. Berkeley/Los Angeles/Oxford: University of California Press.

Bakhtin, Michael (1982), The Dialogic Imagination. Four essays. Austin: University of Texas Press.

Bal, Mieke; Crewe, Jonathan; Spitzer, Leo (eds.) (1999), Acts of Memory: Cultural Recall in the Present. Hanover: University Press of New England.

Banville, John (2000), "Review of J. M. Coetzee, Disgrace," The New York Review of Books, 20 January, 23-25.

Barthes, Roland (1980), La chambre claire. Paris: Gallimard.

Benjamin, Walter (1974), "Das Kunstwerk im Zeitalter seiner technischen Reproduzierbarkeit," Gesammelte Schriften. Unter mitwirkung von Theodor Adorno und Gershom Scholem. Vol. 1, Part 2: 471-508. Frankfurt am Main: Suhrkamp Verlag.

Boehmer, Elleke (2002), "Not Saying Sorry, Not Speaking Pain: Gender Implications in Disgrace," Interventions, 4, 342-351.

Braidotti, Rosi (2006), Transpositions. Cambridge: Polity Press.

Butler, Judith et al. (2000), What's Left of Theory. New Work on the Politics of Literary Theory. New York and London: Routledge.

Carter, Angela (1983), "Notes from the Front Line," in Michele Wandor (ed.), On Gender and Writing. London: Pandora Press, 69-77.

Cixous, Hélène (1975), "Le rire de la Meduse," L'Arc, 61, special issue on Simone de Beauvoir et la Lutte des Femmes, 39-54.

Coetzee, Carli; Nuttall, Sarah (eds.) (1998), Negotiating the Past: The Making of Memory in South Africa. Oxford: Oxford University Press.

Coetzee, J.M. (1988), White Writing. On the Culture of Letters in South Africa. New Haven and London: Yale University Press.

Coetzee, J.M. (1992), Doubling the Point: Essays and Interviews. Cambridge/London: Harvard University Press.

Coetzee, J.M. (1999), Disgrace. London: Secker \& Warburg, 1999.

Culler, Jonathan (1981), The Pursuit of Signs. London: Routledge. 
Culler, Jonathan (1983), On Deconstruction. Theory and Criticism after Structuralism. London: Routledge.

Culler, Jonathan (2000), "The Literary in Theory," in Judith Butler et al., What's Left of Theory. New Work on the Politics of Literary Theory. New York and London: Routledge.

Gorra, Michael (1999), "'After the Fall', Review of Disgrace, by J. M. Coetzee," New York Times on the Web, 28 November: http://www.nytimes.com/books/99/11/28/reviews/991128.28gorrat.html.

Heusden, Barend van (2001), Literaire Cultuur. Nijmegen: SUN.

Jansen, Ena (2005), "Ek het maar net saam met die meisies gebly. Die representasie van vrouebediendes in die Suid-Afrikaanse letterkunde," STILET, March, 102-133

James, Wilmot; van de Vijver, Linda (eds.) (2001), After the TRC: Reflections on Truth and Reconciliation in South Africa. Claremont/Athens: David Philip/Ohio University Press.

Kristeva, Julia (1974), La revolution du language poetique. L'avant-garde à la fin du XIXe siècle. Paris: Editions du Seuil.

Krog, Antjie (2004), "Reading with the skin: Liberalism, race and power in Age of Iron and Disgrace by J. M. Coetzee," in Kader Asmal (ed.), In His Own Words. Boston: Little, Brown and Company.

Mamdani, Mahmood (2001), "A Diminished Truth," in Wilmot James and Linda van de Vijver (eds.), After the TRC: Reflections on Truth and Reconciliation in South Africa. Claremont/Athens: David Philip/Ohio University Press, 58-61.

Minow, Martha (1998), Between Vengeance and Forgiveness: Facing History after Genocide and Mass Violence. Boston: Beacon.

Morrison, Toni (1992), Playing in the Dark. Whiteness and the Literary Imagination. Cambridge MA: Harvard University Press.

Niekerk, Marlene van (2006), Agaat. First English translation by Michiel Heyns and Marlene van Niekerk. Jeppestowwn, South Africa: Jonathan Ball Publishers.

Olivier, Gerrit (2003), “J.M. Coetzee: Plesier en Ontwrigting," Insig, November 2003 (Kalahari.net).

Postel, Gitte (2006), Unheimlich moederland. (Anti-)pastorale letteren in Zuid-Afrika. Leiden: Leiden University Press.

Rossouw, Johann (2005), "O moenie huil nie, o moenie treur nie, die jollie bobbejaan kom weer," Vrye Afrikaan (http://vryeafrikaan.co.za/lees.php?id=105).

Sontag, Susan (1964), Against Interpretation. New York: Dell Publishing.

Spivak, Gayatri Chakravorty (1985), "Three Women's Texts and a Critique of Imperialism," Critical Inquiry, 12(1), 243-61.

Spivak, Gayatri Chakravorty (2003), Death of a Discipline. New York: Columbia University Press.

Visagie, Andries (2007), "Agaat as kultuurdokumentasie vir die toekoms," LitNet, 6-13 February (http://www.litnet.co.za/cgi-

bin/giga.cgi?cmd=cause_dir_news_item\&news_id=17768\&cause_id=1270). 